\title{
THE SWEDISH STORY ABOUT IMPORT OF LIVE CRAYFISH
}

\section{EDSMAN}

Institute of Freshwater Research, National Board of Fisheries, SE-17893 Drottningholm, Sweden.

E-mail: lennart.edsman@fiskeriverket.se

Reçu le 29 janvier 2004

Received January 29, 2004

Accepté le 8 avril 2004

Accepted July 5, 2004

\begin{abstract}
The Swedish market for freshwater crayfish is attractive since a high price is paid for the crayfish. Before 1997 the import of live crayfish was regulated and required application, import permit, veterinary border control and approved boiling places. In august 1997 four paragraphs were removed from the import legislation, resulting in an almost open border to live crayfish import, regardless of species or country of origin. This seriously increased the threat to the work of conserving the native noble crayfish, with the possibility of new species and diseases entering the country. An account will be given of what has happened during six years to solve this problem and of which actors (authorities, organisations, media) have taken part in the process. Eventually, since august 2003 three new paragraphs in the environmental legislation are in force and all import of live crayfish from abroad is prohibited.
\end{abstract} astacus.

Key-words: Crayfish trade, import legislation, conservation, noble crayfish, Astacus

\section{HISTORIQUE SUÉDOIS DE L'IMPORTATION DES ÉCREVISSES VIVANTES}

\section{RÉSUMÉ}

Le marché suédois des écrevisses est attractif depuis qu'elles sont à un prix élevé. Avant 1997, l'importation d'écrevisses vivantes était modulé et exigeait un permis d'importation, un contrôle douanier vétérinaire et des sites de cuissons approuvés. En août 1997 quatre paragraphes ont été supprimés de la législation sur l'importation, avec pour conséquence une quasi-ouverture des frontières aux importations d'écrevisses vivantes, quels que soient l'espèce ou le pays d'origine. Ceci a sérieusement aggravé les menaces pesant sur le travail de conservation de l'écrevisse noble native, en augmentant la possibilité pour de nouvelles espèces et maladies d'entrer dans le pays. Un compte rendu sera donné sur ce qui s'est passé durant les six années pour résoudre ce problème et sur les acteurs (autorités, organisations, média) qui ont participé au processus. Depuis août 2003, trois nouveaux paragraphes dans la législation environnementale sont en vigueur et toute importation d'écrevisses vivantes est actuellement prohibée.

Mots-clés: Commerce des écrevisses, législation d'importation, conservation, écrevisses nobles, Astacus astacus. 


\section{BACKGROUND}

For over 100 years there has been a great interest in crayfish and crayfish fishery among the general public in Sweden and these strong traditions are connected to the yearly, almost ritual, crayfish festivals in August where a large part of the Swedish people take part. Crayfish thus represent a large cultural, social, recreational and economic value. As an indication of its cultural importance noble crayfish appears as a symbol in UV-light in the Swedish EU passport, in order to make it forge proof.

The only native crayfish in Sweden is noble crayfish Astacus astacus (SKURDAL et al., 1999). It is estimated that $95 \%$ of the populations have been lost during the last 100 years mainly because of the disease crayfish plague (Aphanomyces astaci), acidification, pollution and competition and spread of the crayfish plague from the introduced signal crayfish Pacifastacus leniusculus (FISKERIVERKET, 1993). Because of the decline in the noble crayfish it is classified as vulnerable in the national Swedish red list for endangered species (GÄRDENFORS, 2000) and an action plan for the conservation of the noble crayfish has been adopted (FISKERIVERKET and NATURVÅRDSVERKET, 1998). As a consequence of the action plan national legislation has become stricter, restocking and liming programs have started, and information programs have been initiated. In the action plan, that was produced in 1997, one of the threats identified was the small import that required permit before 1997, the aquarium trade and the problem with correct species identification and crayfish ending up in natural waters in connection to these trade activities.

Prior to 1997, the importation of live crayfish into Sweden was regulated by the Swedish regulation on import of fish, crustaceans, molluscs or products thereof (SJVFS 1995: 125), issued by the Swedish Board of Agriculture. The import required an application and if a permit was given it contained rules including notification to customs in advance, veterinary control from the border and processing only at approved boiling places were also the containers and water was disinfected. This meant that no crayfish from abroad could be sold live to customers in fish shops.

Introductions of crayfish into water bodies, for any purpose, always require a permit from the County Administrative Board (SFS 1994: 1716). However, coupled with the interest in crayfish, initiatives of the general public and fishermen are common and relocations and stockings of live crayfish without permits occur both in Sweden and in other countries (LODGE et al. 2000). This may happen because people are either unaware of the rules or the risks associated with translocations or because they do not care about the legislation and only want a population of crayfish in waters close by, regardless of the consequences. Crayfish are of course also unaware of the legislation and when large quantities of live crayfish are handled escapes are almost unavoidable.

One of the most instructive historical examples of what may happen through trade with live crayfish is the example of how Sweden almost a hundred years ago got the crayfish plague with a shipment of live crayfish imported as food from Finland. On arrival the crayfish were in bad condition and they were tipped into a lake close to the fish market in Stockholm (Figure 1). This happened in August 1907 when the authorities where already aware of the disease, the consequences it had had for native European crayfish species in other countries and the risks with live trade. An import ban was imposed in September 1907 , which was then too late.

The risks and the negative consequences connected to translocations and trade with live crayfish have been highlighted internationally by resolutions (IAA, 1987; ROGERS, 2002), and have been a main topic of discussion at several meetings of the International Association of Astacology as well as other international meetings (e.g. GHERARDI and HOLDICH, 1999; SOUTY-GROSSET and GRANDJEAN, 2002) 


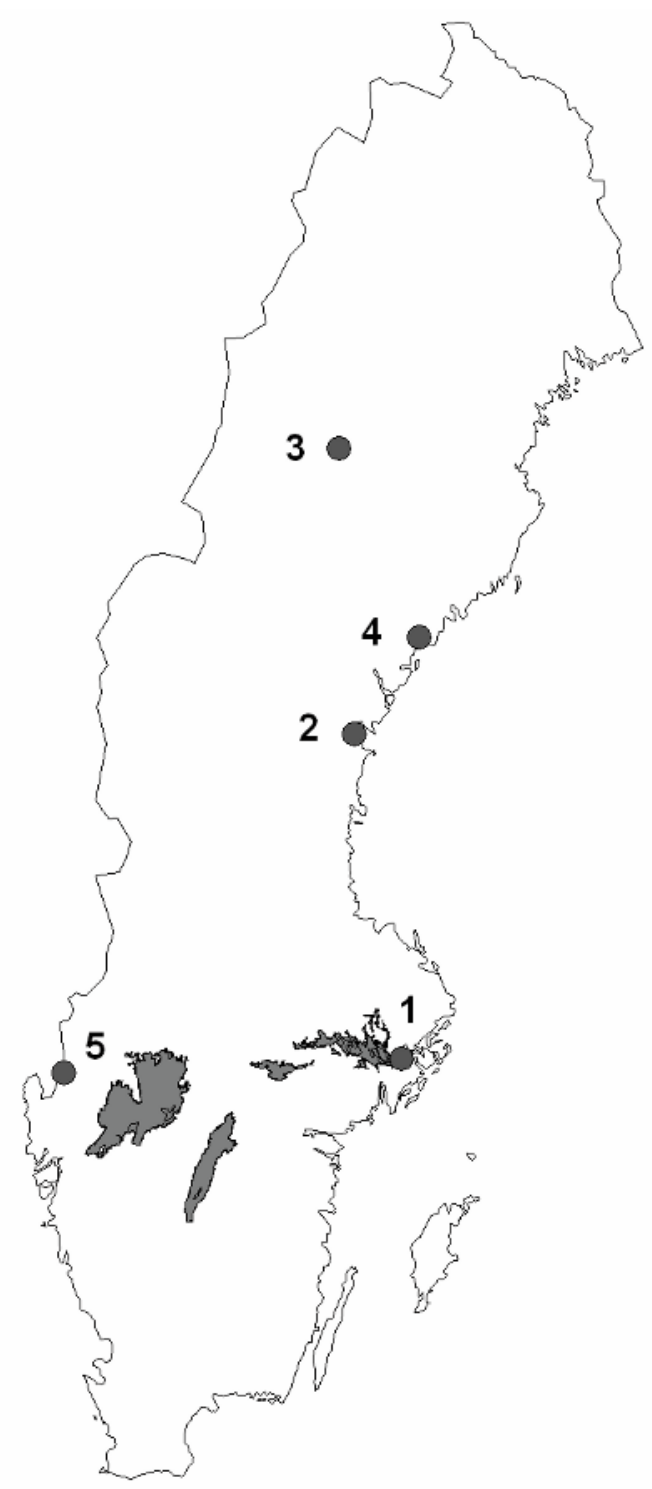

Figure 1

Map of Sweden indicating the location of events mentioned in the text: 1) Crayfish plague arrives to the country with a shipment of live crayfish from Finland to Stockholm in 1907; 2) Live Astacus leptodactylus from Turkey is sold in fish shops in Sundsvall in 1998; 3) Illegal introductions of signal crayfish in two lakes discovered in Northern Sweden in 2000; 4) A shipment of live Astacus leptodactylus from Armenia is stopped by the Municipality of Örnsköldsvik in 2001; 5) Several illegal introductions of signal crayfish are discovered in Lake Stora Le bordering Norway in 2002.

\section{Figure 1}

Carte de la Suède indiquant la localisation des évènements mentionnés dans le texte : 1) introduction de la peste de l'écrevisse dans le pays avec un arrivage d'écrevisses vivantes à Stockholm en provenance de Finlande en 1907 ; 2) Vente d'écrevisses vivantes Astacus leptodactylus en provenance de Turquie dans les poissonneries de Sundsvall en 1998 ; 3) Découverte d'introductions illégales d'écrevisses signal dans deux lacs du Nord de la Suède en 2000 ; 4) Interception d'une cargaison d'écrevisses vivantes Astacus leptodactylus en provenance d'Arménie, par la municipalité de Örnsköldsvik en 2001; 5) Découverte de plusieurs introductions illégales d'écrevisses signal dans le lac Stora Le, à la frontière norvégienne en 2002. 


\section{THE MARKET}

The import of crayfish from abroad has varied between 1500 and 3000 tons yearly over the last ten years. The main part of the import of crayfish is in the form of already processed and frozen or vacuum-packed crayfish and import of live crayfish only constitutes a fraction, or a few percent of the total. It is also estimated that between 1000 and 1500 tons of crayfish is fished out of Swedish waters by private fishing right owners yearly but the figures are based on questionnaires and the estimate is uncertain. Taken together on average nearly $0.5 \mathrm{~kg}$ of crayfish is consumed per person and year in the country.

The price per kilo in shops varies between 7 euros (for small size frozen Chinese Procambarus clarkii on sale) to 90 euros (for freshly boiled Swedish noble crayfish of large size) in the most expensive fish shops. Noble crayfish pays at least twice the price of signal crayfish. The market is demanding and the quality of the crayfish is vital. Only well tasting nice looking crayfish of large size with two claws fetches a high price. Every year all newspapers contain evaluations of the products available for sale and a panel classifies the crayfish on the market on a scale from terrible to excellent, to guide people buying crayfish for the festivals in August. Because of the high price paid for crayfish the Swedish market is very attractive and there is a great interest in exporting crayfish to Sweden.

\section{THE CHALLENGE AND ITS CONSEQUENCES}

In summer 1997 an English crayfish farmer applied and got a permit to export live crayfish to Sweden. At the same time the European Commission (EC) was contacted and the question was asked if these kind of permits, and the rules that went with the permit, were in agreement with the principles of free trade. In August the Swedish Ministry for Foreign Affairs was contacted by the EC and informed that this case may be tried in the European Court of Justice to see if it was in agreement with the rules of free trade, if measures where not taken.

On September 1, 1997 four paragraphs concerning import of live crayfish were removed from the import legislation. The result was that live crayfish could be imported as food into Sweden regardless of country of origin and species. The removal of the paragraphs also meant that the legislation did not distinguish between import from countries inside or outside the EU. Thus Sweden quickly went from having quite strict regulations, to being the country within the EU with the most open border to import of live crayfish from countries outside the EU, that is no restrictions at all as long as the crayfish where fit for human consumption. Live crayfish from abroad could now start to appear in the country and could also be sold live to customers in fish shops. Neither all the authorities nor the market quite anticipated what had happened at first.

\section{ACTIONS AND INCIDENTS}

The following is a chronological account of the main events and actions with implications for the question of the crayfish trade and mainly include those events that have been covered in media.

In August 1998 a Fisheries Officer at the County Administration discovered that narrow-clawed crayfish, Astacus leptodactylus, imported from Turkey was sold live for consumption in fish shops in north Sweden (Figure 1). Unfortunately the shop owner also informed the customers that this species would not survive in Sweden, a statement that is doubtful since there are reproducing populations of this species in e.g. Finland.

In August an employee at the National Board of Fisheries wrote a letter to the Minister of Agriculture. The letter pointed out the risks connected to the present situations 
with the possibility of getting new diseases or new crayfish species into the country and the negative effects this would have for the conservation of the noble crayfish. It also pointed out that several other European countries, e.g. Ireland and Norway, had an import stop for alien species and that all other EU countries had some kind of restrictions regarding live crayfish trade from countries outside the EU. This got a wide coverage in TV, radio and newspapers and was followed by several newspaper articles from university researchers and organisations agreeing with the risks with the present import legislation.

The World Wildlife Fund sent a proposal to the Ministry of the Environment in October, warning for the risks and suggesting that the problem may be solved by regulations in the Species Protection Act connected to the recently adopted Swedish Environmental Code.

In October one of the members of the parliament posed a question to the Government asking what was being done regarding the problem of import of live crayfish.

In October the Federation of Fishing Right Owners published an article in their journal about the trade with live crayfish and also contacted the Ministry of Agriculture expressing concern about the present situation and asking for actions to be taken.

In July 1999 the main news program on the radio revealed that noble crayfish imported from Monte Negro had been sold as Swedish in two of the three most exclusive fish shops in Stockholm last year. The statement was based on a preliminary molecular genetic study by the Institute of Freshwater Research utilizing microsatellite markers (EDSMAN et al., 2002), although the researchers said that the case was not $100 \%$ proven. In an interview the owner to the two shops, that sold crayfish labelled with the wrong nationality, admitted that there must have been some mix-up from unexperienced employees. Noble crayfish from Sweden was sold at a price $40 \%$ higher compared to the noble crayfish from Monte Negro. This shows that the origin of crayfish can easily be changed with small possibilities of detection.

In August WWF repeated the proposal to the Ministry of the Environment from 1998 to solve the question with free crayfish trade with the Species Protection Act. They stressed that the border had now been open two years, that time might be running out and that quick action was needed.

In summer 2000 it came to the attention of the Institute of Freshwater Research that noble crayfish imported live to Sweden from Monte Negro was reloaded at the airport of arrival and shipped to Finland. This was possible since once in Sweden the crayfish were inside the open EU market and Sweden now functioned as the least restrictive gate to this market.

The Swedish Board of Agriculture was contacted in September 2000 by an importer intending to start importing live crayfish and wanting to know which rules applied to import of live Orconectes rusticus. He got the answer that there were no restrictions to such an import at the moment. This species is known to cause severe damage to other crayfish species and the ecosystem when translocated in the USA (LODGE et al., 2000).

In October one of the members of the parliament again posed a question to the Government asking what was being done regarding the problem of import of live crayfish and got the answer that the authorities were working on solutions to the problem. The question was repeated in 2001 and the topic was also discussed within the working group for agricultural questions in the parliament.

In October the National Board of Fisheries sent out a press release since a questionnaire to all County Administrative Boards in Sweden revealed that 18 of the 21 counties had illegal introductions of crayfish discovered during the last two years. It was not known if these introductions were deliberate or accidental. The worst example 
was an introduction of signal crayfish, probably bought as food, in the North of Sweden (Figure 1) more than $400 \mathrm{~km}$ further north of any localities that had ever been given permits for introductions. The board warned that these introductions in many cases might hamper the work with conservation of the native noble crayfish. The press release got a good coverage in media.

A small shipment $(1 \mathrm{~kg})$ of what was supposed to be live Astacus astacus from Poland was imported to Sweden in November as a first trial to evaluate the possibilities of a larger import. Neither the importer nor the customs to which the crayfish was shown reacted. By chance it was discovered that the crayfish belonged to the species Orconectes limosus. This shows that species identification is difficult and the incident was covered in radio and newspapers.

In December the National Board of Fisheries produced a report on the risks connected to the free crayfish trade. The report was not a scientific risk analysis but a summary of the Swedish obligations concerning the conservation of biodiversity, the occurrence of deliberate and accidental crayfish translocations nationally and internationally and the consequences that they have had.

In August 2001 a Municipality in northern Sweden (Figure 1) stopped the import of a shipment of live Astacus leptodactylus originating from Armenia, using the principle of caution in the newly adopted national environmental legislation. The processing plant of the importer was situated in close connection to a Natura 2000 site with strong populations of noble crayfish.

In Summer 2002 several populations of signal crayfish were discovered in a large lake in western Sweden, bordering Norway (Figure 1), where no permits for introduction had ever been given. This part of the country holds many good noble crayfish populations. The signal crayfish were analysed and found to be carriers of crayfish plague. Illegal introductions were also reported from many other parts of the country. In October the National Board of Fisheries again issued a press release informing about the legislation, stating that such introductions and translocations of native and foreign crayfish without permit are illegal and warning for the consequences.

\section{MEETINGS}

After the problems and risks with the almost open border for crayfish trade had been highlighted several times in media and elsewhere, a joint effort to look at the possibilities for a solution was initiated in August 1999. Apart from a lot of direct communication between people at the different authorities, 9 more or less official meetings were held, two in 1999, 6 in 2000 and one in 2001. Participants included people from four boards or agencies and three ministries; National Board of Fisheries, National Food Administration, Swedish Board of Agriculture, and Swedish Environmental Protection Agency, Ministry of Environment, Ministry of Agriculture and Ministry of Foreign Affairs.

In the first two meetings only boards and agencies took part. It was found that to make progress the work had to include authorities at a higher level. In November 1999 the Ministry of Environment started taking part, in April 2000 the Ministry of Agriculture joined and in November 2000 the Ministry of Foreign Affairs joined the meetings. At the meeting in June 2000 it was decided that environmental legislation was best suited to solve the problem and that the Ministry of Environment should have the main responsibility for the continued work. In the last meeting in March 2001 only the ministries involved took part. 


\section{THE NEW LEGISLATION}

Starting in April the Ministry of Environment produced 5 proposals for a new legislation during 2001. Several of these were committed to authorities, companies and organisations for comments and opinions. After a pause in 2002 three more suggestions were distributed starting in August. The proposal with a formulation of the new legislation was finalised in October 2002.

In October the proposed changes in the Species Protection Act were notified, according to the rules, to the European Commission and the World Trade Organisation for comments and opinions by the member states. The content of the proposal was to stop all import of live crayfish from abroad. The purpose of the changes in legislation was to protect the endangered native noble crayfish. The changes were motivated by the endangered status of the noble crayfish and Swedish obligations for the conservation of biodiversity, the measures taken within the country to protect the species and by the threat to the noble crayfish that trade with live crayfish from abroad poses, even when being only a fraction of the total crayfish trade, with the risk of new species and new diseases getting established in the country.

Apart for a couple of questions of technical nature that were clarified, no objections had been received by the member states when the time for responses was ended in January 2003.

In June the Government decided to include the three new paragraphs in the final proposal into the Species Protection Act (SFS 1998: 179) connected to the environmental legislation and they came into force August 1, 2003. In short all import, transportation, and storage of live freshwater crayfish from abroad was prohibited. These rules also apply to the aquarium trade.

\section{WHAT CAN BE LEARNT}

Once legislation has been changed in one direction it takes a long time to make new changes. In the beginning it took some time to decide who should have the main responsibility for tackling the problem. In the case of Sweden crayfish plays many roles. They are food, the main part of the ritualised crayfish festivals in August, a red listed protected species or an introduced species, an agent for the spreading of diseases and a group of animals of great commercial value. Therefore people from three Ministries and four Boards or Agencies handled the question of the legislation at the national level. As time passed some people finished their employment or moved to other positions and through these exchanges up to five different people at the different authorities have been in charge of the crayfish trade question. On occasion this meant starting all over again.

The media obviously played a large part in bringing the topic of crayfish import up to the surface again and again. Because of the interest information about crayfish, regardless of topic, makes good news in Sweden. Every year in connection to the fishing season and the crayfish parties in August it is essential for newspapers, journals, TV and radio to have articles and release news about crayfish. Articles about illegal introductions or fish shops cheating with origin of species are especially appreciated because they make good headlines. The journalists demand news about crayfish and if you are prepared when contacted it may be possible to get the information you want out in media and to the general public. People working within the Government and other authorities are part of the general public and it was evident that the work with live crayfish trade at the authorities was speeded up when the topic had been highlighted in media.

In 1997 it was said to be almost impossible to maintain the rules Sweden had regarding import of live crayfish because of forcing directives and the strong position 
of the rules of free trade. In the end it turned out to be possible, maybe because environmental legislation instead of disease control legislation was used. This may also reflect that environmental considerations and conservation issues have a stronger position today compared to six years ago, both nationally and in the EU.

\section{REFERENCES}

EDSMAN L., FARRIS J.S., KÄLLERSJÖ M., PRESTEGAARD T., 2002. Genetic differentiation between noble crayfish, Astacus astacus (L.), populations detected by microsatellite length variation in the rDNA ITS1 region. Bull. Fr. Pêche Piscic., 367, 691-706.

FISKERIVERKET, 1993. Ways of increasing populations of noble crayfish Astacus astacus in Swedish fresh waters. Information from the Institute of Freshwater Research, Drottningholm, 2, 1993, 1-66. (In Swedish with English summary).

FISKERIVERKET and NATURVÅRDSVERKET, 1998. Action plan for the restoration of the noble crayfish in Sweden. JÄRVI T., THORELL L. (Eds), Fiskeriverket and Naturvårdsverket, Göteborg and Stockholm. 38 p. (In Swedish).

GHERARDI F., HOLDICH D.M. (Eds.), 1999. Crayfish in Europe as alien species. How to make the best of a bad situation?, Balkema, Rotterdam, $299 \mathrm{p}$.

GÄRDENFORS U. (Ed.), 2000. The 2000 red list of Swedish species. ArtDatabanken, SLU, Uppsala.

IAA, 1987. Resolution (adopted by the IAA General Assembly in Lausanne). Freshwater Crayfish, 7, XI.

LODGE D.M., TAYLOR C.A., HOLDICH D.M., SKURDAL J., 2000. Nonindigenous crayfishes threaten North American freshwater biodiversity. Fisheries, 25 (8), 7-20.

ROGERS D., 2002. IAA resolutions paper. State of crayfish conservation: threats and future directions. Freshwater Crayfish, 13, 621-623.

SKURDAL J., TAUGBØL T., BURBA A., EDSMAN L., SÖDERBACK B., STYRISHAVE B., TUUSTI J., WESTMAN K., 1999. Crayfish introductions in the Nordic and Baltic countries. In : GHERARDI F. and HOLDICH D.M. (Eds.), Crayfish in Europe as alien species. How to make the best of a bad situation?, Balkema, Rotterdam, 193219.

SOUTY-GROSSET C., GRANDJEAN F. (Eds.), 2002. Knowledge-based management of European native crayfishes: dialogues between researchers and managers. Bull. Fr. Pêche Piscic., 367 (4), 402 p. 